\title{
"Leave No One Behind" in Education: Empowering Vulnerable Youth towards Self-Sustainability and Social Development
}

\author{
Adi Suryani $1^{*}$, Soedarso ${ }^{2}$ \\ 1,2 Departemen Studi Pembangunan/Fakultas Desain Kreatif dan Bisnis Digital/Institut Teknologi Sepuluh Nopember
}

\section{A R T I C L E I N F O}

Article history:

Received 10 December 2019

Received in revised form

01 January 2020

Accepted 30 January 2020

Available online 28

February 2020

Keywords:

youth education, life skill

vulnerable youth

\section{A B S T R A C T}

Every human being has equal right to obtain proper education which prospectively promotes decent employment and life prosperity. Vulnerable children and youth are potential human resources who should be encouraged to develop themselves and meaningfully contribute to society. This study aims to explore education service and learning for encouraging orphanage youth at Panti Asuhan BJ HabibieSurabaya to be self-sustained and potentially contributes to society. Qualitative method is adopted to meet research objectives. The data are collected through direct participant observation in a community service. The study indicates that life skill education promotes life values which support the orphans to face life challenges. Being able to be selfeducated, developed and discover positive life meaning can be potential investment for the orphans to survive. The growth of contributing and meaningful vulnerable youth requires a caring society who provides just and encouraging climate for the vulnerable to learn, develop and promote intergenerational learning..

\footnotetext{
* Corresponding author.

E-mail addresses: adisuryani.rahman@gmail.com (Adi Suryani)
} 


\section{Introduction}

All people have rights for proper life. They should receive equal opportunities for peaceful, secured, healthy, prosperous and well being living. One of several ways to ensure these basic necessities fulfilment is education. Currently, many people, from generation to generation compete for qualified and up-to-dated education. It is widely believed that education is the key for better, even bright future. Education today is frequently viewed from economical-non economical aspects. It opens access into well-paid or prestigious occupation, which many societies believe as the indicator of successful life.

The life-securing attribute of education supports many people to compete in pursuit of best education. The haves may have a wide range of best school/educational options. They are able to afford the most qualified school, which in turn securing their livelihood. A contrasting condition occurs in disadvantaged people. Poverty, prejudice, discrimination, gender, race, physical area remoteness, disabilities, conflict and emergencies as well as disadvantaged hinder children and adolescence to get their right access. Thus, education is not a value-neutral.

Realizing the enormous significant roles of education, yet it is not a neutral development aspect, global concern is directed to distribute equal access to education, while eliminating its' hindrances. Various efforts are undertaken at different levels: setting equalized educational policies and systems, generating world commitment, mobilizing organizations for campaign and devoting actions, establishing shared responsible international declaration, treaties and conventions for human's education protection and devoting global resources for eradicating education disparities and gaps in developing countries.

The world pledge, leaving no one behind, voices global commitment for actions in supporting all sector development, engaging everyone and delivering towards the benefits of every people. This study aims to explore several lessons extracted from some educational activities provided for the orphan youth in Panti Asuhan B.J Habibie, Keputih. The researchers propose the activities as one of local-scale implementations of leaving no one behind in education field and a potential thrust towards sustainable development. Education is considered as a mean to integrate various development sectors: economic, environment and social using development strategy for building nations, society and families to sustainable future (Chen, Nasongkhla, \& Donaldson, 2015, p. 165).

\section{Methods}

\section{Context of Vulnerability, Research Site and Participants}

Vulnerable youth experience different life condition which may risk their capacity for fullest potential development. Vulnerability is assumed as possible adverse consequences or potential risk which can impoverish one's quality life (Gorur, 2015, pp. 4-5). Frequently, different terminologies are used interchangeably, such as discriminated, stereotyped, marginalized, at risk, to represent children/youth risk causes or probabilities (Gorur, 2015). Different adverse life situation threatens youth from obtaining potential positive life outcomes, including death of parents, criminal behavior, family conflict/separation, pregnancy before/without marriage, drug consumption, sexual harassment, no or lack of education or mental problems (Government of South Australia, n.d., p. 4). Economic, environmental, social and political factors prevent vulnerable youth to reach positive live (Bankoff, 2003, p. 8). Vulnerability is clustered into several categories: street children, labored children, children in conflict area, HIV-affected children, disable children and orphans and vulnerable children (Arora, Shah, Chaturvedi, \& Gupta, 2015). Vulnerable causes can be intersectional and multiple (Alcantara, 2018, pp. 4-5; Gorur, 2015).
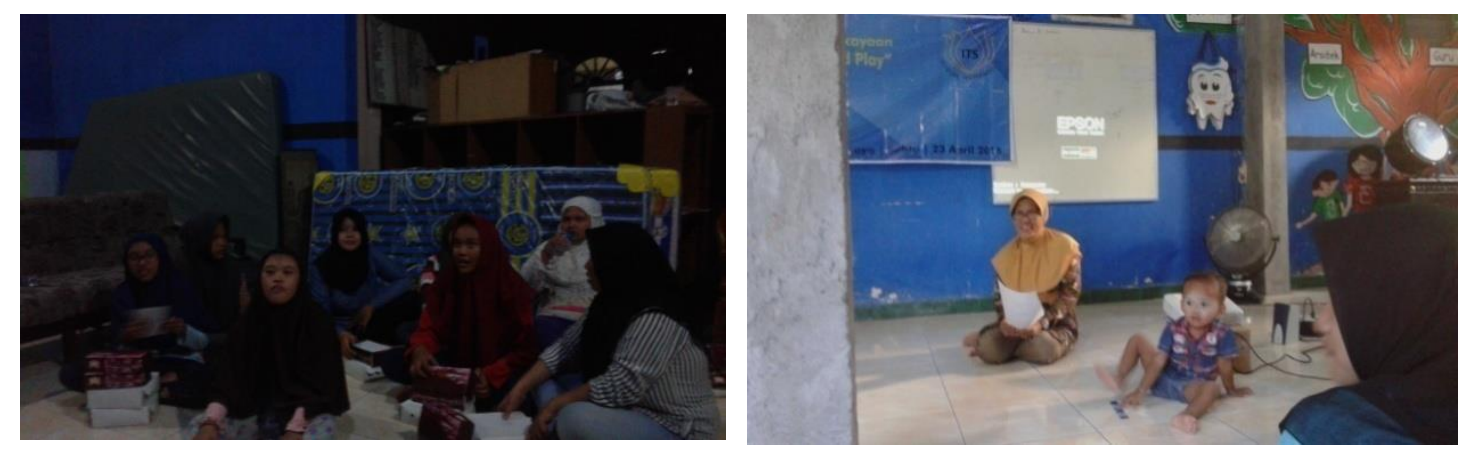

Fig. 1 The learning situation in Panti Asuhan B.J. Habibie 
This study is developed based on community service program at Panti Asuhan B.J. Habibie. During the process of community service, the authors examine some learning aspects: the participating youth behaviour/responses, the suitability of the educational material provided and potential contribution for BJ Habibie youth's self development. The authors aim to extract valuable learning aspects from this community service to be shared and contribute to vulnerable youth education body of knowledge.

The community service and research participants are several orphan youth, cared by Panti Asuhan BJ Habibie, Keputih. Panti Asuhan (orphanage) B.J. Habibie is located in JL. Keputih Tegal I/25, Surabaya, East Java. They are group of vulnerable youth since they grow and live with the absence of one of their parents, even both of them. Panti Asuhan BJ Habibie cares and becomes a place for them to stay and receive protection, nurturance and basic need fulfillments. Those who do not have any parents and extended families to take care of are staying in Panti Asuhan BJ Habibie, while for orphans who are still having one of their parents and extended family are living with them and are supported by Panti Asuhan BJ Habibie. The participants of the education program are 15 orphans at senior high school age and attended by several caregivers. The orphanage is not built by B.J. Habibie. Instead, the founders of Panti Asuhan BJ Habibie expects that in the future, the cared orphans can learn from BJ. Habibie's social awareness character and transform themselves into human with high social care and sensitivity.

\section{Method of Data Collection, Instruments and Analysis}

The research uses direct participant observation. The researchers are occupying multiple roles of becoming the education development facilitating agents in community service program and the direct observers. The aims of the education program are empowering the vulnerable orphans to survive and grow in spite of their adversities. These aims are manifested into two main activities: telling the researchers' meaningful childhood-lived experiences to grow the orphan-participants' resilient and motivation to develop and English language learning to increase the youth motivation to learn English language as one skills required to get better occupations and participate in 21st century development. The data collected from those activities are organized into several main themes. Subsequently, the data are interpreted, interlinked and related with existing studies

\section{Result and Discussion}

The study demonstrates that the orphans (vulnerable youth) at Panti Asuhan BJ Habibie have basic human rights to receive educational concern, at least from the local surrounding society and nearby academic institutions. It is not sufficient to provide teaching on content subject matter only. Their learning capacity should be enhanced with meta-learning, the learning beyond school subject matter, established traditional curriculum as well as learning for tests or examinations. Learning for life resilience and respond the life adverse challenges are required by the orphan (vulnerable) youth. Human rights recognition and commitment need to be extended with real practical program in society (UNESCO, 2005; Unicef, n.d.-a). One of those practices is education for youth empowering at Panti Asuhan BJ Habibie.

\section{Advancing Life Learning Skills}

One of other ways to educationally empower the orphans is by strengthening their life skills. The death of the parent(s) may fragile their life and put them into potential risk in the future. Thus, strengthening life skills is required for developing the orphans' resiliencing and developing capacity.

The life skills learning for the youth at Panti Asuhan BJ Habibie is provided through the researchers' childhood-lived experience life stories. There are 10 life stories which encapsulate life values. These life values are shared to the youth at Panti Asuhan BJ Habibie to allow them learn, understand and take meaning from living experiences. Below are several life values extracted from shared lived experience life stories.

Table 1. Life-stories based extracted values promoting the orphans at Panti Asuhan B.J. Habibie

\begin{tabular}{lll}
\hline No & Life Stories Themes & Extracted Values \\
\hline 1 & Be motivated in spite of being poor & a. Caring animals and environment (1.a) \\
& and suffer from inadequacies & b. Accepting any life condition (1.b) \\
& & c. Keep on motivated in spite of lack of school facilities \\
& & (1.c) \\
& & d.Thankful to The God for any life situation that The God \\
& & gives (1.d) \\
2 & Being Brave, Don't' Run! & a. Face life challenge, don't run (2.a) \\
\hline
\end{tabular}




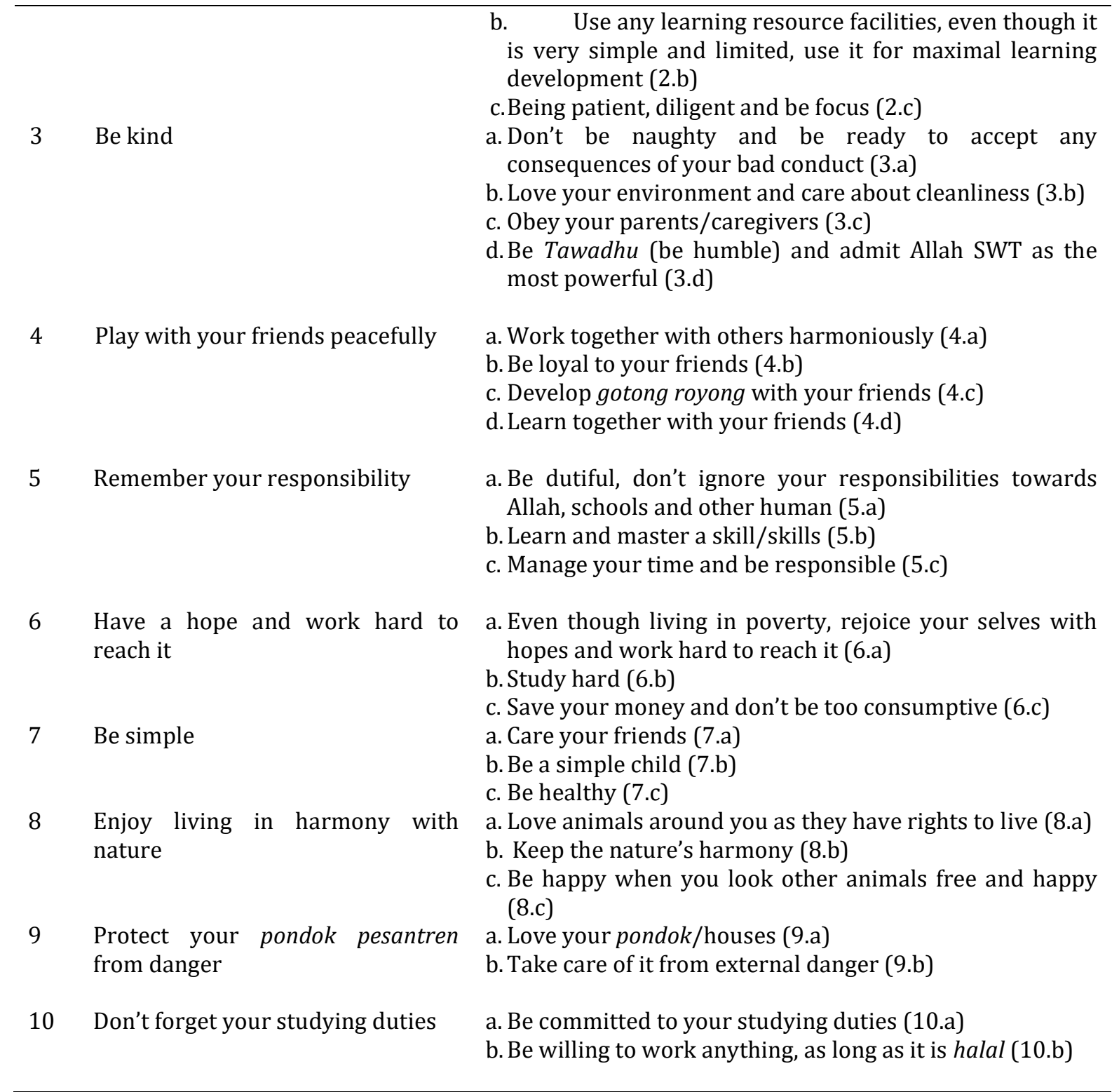

The above extracted values are connected to three orientation of sustainable development: economic, social and environmental development. It is expected that the vulnerable youth can live harmoniously and prosperously in those three-balanced sectors. Sustainable development seeks to achieve the integrated environmental, economic and social development dimensions (Emas, 2015; United Nations, n.d.). Quality education (SDG 4) is the driver of other SDGs, especially SDG 8 for economic growth (KPMG, 2017, p. 7). Table 2 below represents the classification of life extracted values along the dimensions of sustainable development: environment, economic, society.

Table 2. Classifications of the extracted values based on three dimensions of Sustainable Development

\begin{tabular}{ll}
\hline Environment & $\bullet$ Caring animals and environment (1.a) \\
\hline Economic & $\bullet$ Keep on motivated in spite of lack of school facilities (1.c) \\
Self-Social Dimension & • Accepting any life condition (1.b) \\
& $\bullet$ Keep on motivated in spite of lack of school facilities (1.c) \\
& $\bullet$ Thankful to The God for any life situation that The God gives (1.d) \\
& $\bullet$ Face life challenge, don't run (2.a) \\
\hline
\end{tabular}

The study indicates several findings related to life skill learning for the vulnerable youth to create a sustained generation. The first dimension is the need to move from traditional educational curriculum towards life learning as a response of today's life challenges. Quality education and ESD (education for 
sustainable development) requires education reorientation by inserting life skill methods (UNESCO, 2015).
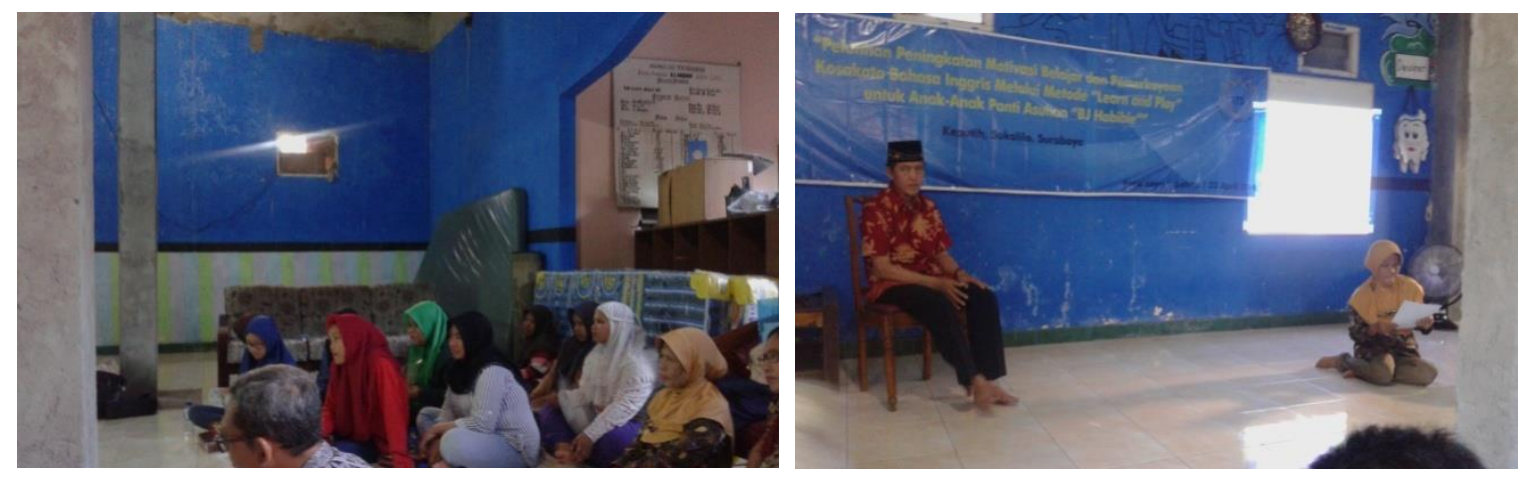

Fig. 2 The life-skill learning process in Panti Asuhan BJ Habibie

Secondly, the life values provided can potentially promote and develop the youth's self-efficacy, social and economic condition, while living in harmony with nature. The researchers expect that through real life stories, the vulnerable youth can emotionally absorb the educated meaning to be implemented for their personal as well as social development. The life skill education contributes to human development in personal and social spheres, prohibit health issues and implementation of human rights (World Health Organization, 1999, p. 2). Life skills can be advanced through decision making learning, creative thinking, interpersonal and communication capacities, self-awareness and emotional and stress management (World Health Organization, 1999, p. 2). The third dimension is it may help create sustainable learning, in which the youth can be triggered to learn and re-learn along their life courses/spans. As the world is constantly changing, the youth will face different life contexts which need them to be able to educate their own selves or be the self-educators. Learning throughout whole life should be the basis for human/people contribution towards sustainable development, instead of limiting people's learning on traditional foundation paradigm of numeracy, literacy and technological mastery (Webb, Holford, Hodge, Milana, \& Waller, 2019, p. 239). Lifelong learning aids people's life to be responsive to the changing world and future needs as well as "learning to be" (The Faure Report, 1972, cited in Atchoarena, 2019, p. 5), for life transformation (UNESCO, n.d.), tacking and responding to life challenges and risks (Unicef, 2012), advance sustainable development achievement (English \& Carlsen, 2019). The recommended provided life skills are manual and psychosocial abilities (UNESCO, 2005), daily-rooted experience and civic engagement (Unicef, 2017, p. 2), livelihood and practical skills, health skills, physical skills as well as behavior- and interaction-related skills (Unicef, n.d.-b).

The data of the extracted values also indicate the provision of self and social skills. The self skills are indicated by accepting one's life condition, being harmony with his/her own self and build self capacity, while social skills are developed through environmental care, school characters, peer/interpersonal relationship, behavior to parents, empathy and working attitude. Self-knowledge, interpersonal relationship and creative-critical thinking are several life-skills for youth empowerment (Unicef, n.d.-b).

\section{Potential Vulnerable Youth Participation in global community}

Vulnerable youth are entitled to contribute to global community and development. Panti Asuhan BJ Habibie's youth are also provided with English language teaching. It is delivered in a fun vocabulary building games. It aims to increase the youth's English language vocabulary, with the main objective is to increase youth motivation to learn English language. The English language plays key roles in world development since it is the main language in global interrelationship building, world science and knowledge progress and global community life. Language is one of core elements in education (UNESCO, $2000 \mathrm{~b}$, p. 65). To respond the globalization, language, general knowledge and science should be continually up dated and young people should be helped to adapt to the changes (UNESCO, 2000b, p. 65). Thus, it is vital to include English language skills in vulnerable youth education as a skill for development.

Through educational English games, it is expected that the motivation of the youth at Panti Asuhan BJ Habibie will increase. The game is designed and executed together by the team. It is a group competition game, in which each of the team should be able to guess the English language (vocabulary) of certain words and sentences through whispering from one member to other member (in whispering game) and through some physical movements acted by the team members (in action-word game). Besides 
increasing passion to learn English language, the games are expected to instill in-group cooperative characters.

The study also demonstrates giving them fund/donation only is not adequate. Soft education is needed for enabling BJ Habibie youth to develop themselves in obtaining proper occupation. The English language education provision should be distributed equally to all children and youth in Indonesia, including vulnerable and disadvantaged ones. The assumption that English language education is expensive and can be reached by children/youth from high economic class, who can afford international school fee, should be eliminated. Access towards English language education for vulnerable-orphan youth should be widened. The English, Indonesian and local/indigenous languages are some main language needed for the Indonesian society to participate in international society in the 21st century (Jokowali, Wicaksono, \& Rosyadi, n.d.). Today, English language is one of several employment skills preferred by many national-scale industries and companies in Indonesia. Decent occupation is vital for youth for ensuring their future life, which also will impact on society and nation's economic growth (United Nations, 2018, p. 35). All youth are entitled to get access into proper employment which provides mobility, standard and equal wages, as well as job security (United Nations, 2018, p. 36). The globalization and information-technology development creates many new jobs and opens access for international-scale enterprises to enter developing countries employment sectors, impacts on changing labor markets and motivates youth to improve skills (United Nations, 2018, p. 36).

Through the English language skills, BJ Habibie youth is expected to be able to join social global participation, especially when they grow up later and can help other vulnerable-orphan to survive and grow. Youth are assets who can be developed to be social workers in civic engagement (Schuster \& Pritzker, 2015, p. 96). They can be volunteers who have enormous young energy and vitality.

Through the English language skills, BJ Habibie youth is expected to be able to join social global participation, especially when they grow up later and can help other vulnerable-orphan to survive and grow. Youth are assets who can be developed to be social workers in civic engagement (Schuster \& Pritzker, 2015, p. 96). They can be volunteers who have enormous young energy and vitality.

\section{Caring and Responsible Society}

This study also shows that BJ Habibie youth education requires a caring society. All segments of society should be involved through active engagement, including university/higher education institution. This education program is one of our practices in community service and building, as part of university dedication and contribution for society development. Panti asuhan BJ Habibie is one of our neighbouring societies who should be empowered through many ways. Education is one of development sectors which can potentially empower and prepare BJ Habibie youth through self-development (self-efficacy, lifelong learning motivation and life skills) and a global skill (increasing motivation and self-efficacy to learn English language).

Today, higher education institutions expand their roles to build partnership and contribute to society. University impacts society in several ways: organizational (how organization influences natural and social environment), education (shapes citizen's values and ethics on interpreting and constructing world), cognition (produces, develops and disseminates knowledge and sciences) and social (social progress and social responsibility) (Vallaeys, n.d., pp. 91-92). Higher education participates in society building through various ways: university social responsibility (Chen et al., 2015; Crowther \& Aras, 2008; Dima, Resch, Borcos, \& Janžekovič, 2016; Esfijani, Hussain, \& Chang, 2013; EU USR, 2015), community service and service learning (Strand, Marullo, Cutforth, Stoecker, \& Donohue, 2003; Wade, 1995). Universities are also expected to build community-university partnership (Ward \& Wolf-Wendel, 2000, p. 767) through community-based researches and community services.

Children and youth have right to obtain decent education from their parents, as their immediate social agents. As orphans do not have parents, the main or core responsible social agents in education (Swick, 2006), society should responsible to help (Glenn, 2000, p. 90). People have right to be cared by state, as the principle bearer, instead of relying on their family (Finch, 1996, cited in Glenn, 2000, p. 90). Thus, youth right to education relates to a caring society development.

A caring society will care each other. It is a just society (Glenn, 2000, p. 84). Even though state bears responsibility for its' citizenship well-being and protect their rights, it is the citizenship's duty to care each other, to other communities, people and families (Torjman, 1998, p. 4). A caring society is actively engaging in eliminating poverty, investment widening, society members' participation, problem solving, partnership, leadership building and celebration (Torjman, 1998, p. 4). A member of caring society has right to care and be cared (Glenn, 2000, p. 88). Everyone has right to be cared and this caring behavior and action can be practiced in many ways (Glenn, 2000, p. 87). However, a caring society cannot be built only through university-community partnerships. Wide range collaboration is needed (Torjman, 
1998, pp. 2-3). Thus, developing Panti Asuhan BJ Habibie youth requires collaborative measures and care from its' surrounding community, academic institution, private enterprises and government. Cares and social concern are devoted by several institutions, including HIMIT (Himpunan Mahasiswa Teknik Informatika)/ Informatics students' association of PENS, SS (Suara Surabaya) Media, LSMs (Social community associations), personal/family, PT Sinar Gramedia.

Caring for Panti Asuhan BJ Habibie youth is a means for experienced-based education, both for the community service team and Panti Asuhan BJ Habibie youth. It provides a role and behavioural model for them. It is expected that the caring act can be transferred inter-generationally from their generation to their younger sister/brother generation. Then, caring as one of exemplary conducts can be passed down. Youth characters are shaped and developed by their social environment (Boomkens, Metz, Schalk, \& Van Regenmortel, 2019), caring and peaceful children are created by families and educators (Swick, 2006) and moral characters are learnt and internalized in social context through community membership, relationship and engagement on the basis of social interdependence (Nucci \& Narvaez, 2008). Caring character are grown through intentional caring education, caring norms commitment, caring attitude practice, feedback and caring guidance (Swick, 2006, pp. 281-282). Modeling, dialogue, practicing and confirming are several approaches to care ethics education (Nucci \& Narvaez, 2008, pp. 167-172). Through observational learning on the transferred caring behavior, BJ Habibie youth can learn to care others. This potential future caring transmission transforms the concept of performing development act for community into doing development act with community, as the cared BJ Habibie youth can be the next partner or intergenerational agents in reaching sustainable development. Since sustainability of development requires continuity, children and youth education as the continuing developers is a basic necessity. Doing actions with community means mutually engages with community to solve local issues (Ward \& Wolf-Wendel, 2000, p. 770).

\section{Youth Education towards Sustainable Development}

The study demonstrates that the development pledge, leave no one behind, should not be interpreted as a passive encouragement, in which the entitled youth has right without meeting the required skills and capacities for obtaining the right. The vulnerable youth should develop themselves to be entitled to reach right they deserve in a meaningful encouraging society. Life learning is one of many education should be provided for vulnerable youth to empower them in meeting life dynamics and challenges. The empowered youth can contribute to society development, while maintaining peaceful environment and sustaining development inter-generationally. The English skill education is an addedskill for facilitating youth's global communication and contribution to the world development. This youth education needs a caring society which provides learning climate, a role model agent, a behavioural model and caring education. Through this caring action, development can be sustained from generation to generation.

The study also shows that integrated sustainable development goals can be achieved through development elaborations. All goals are interlinked since they are functioning in a dynamic, interdependent and interrelated physical and social environment. The interrelatedness operates across different periods and generation in which damages and development are not only impacting today society, but also future humankind as well as today's society are in efforts to manage the past damage consequences. This interrelatedness is also across different countries. Thus, the world sustainable plan is re-interpreted and contextually re-constructed in Indonesia in Nawacita. The development programs in Nawacita are relevant to world's SDG's programs, including human development, welfare and education, sustainable economic, energy access and climate changes (Hoelman, Parhusip, Eko, Bahagijo, \& Santono, 2016, pp. 12-13).

The success of B.J. Habibie's youth education development effort is dependent on interrelationships of other sustainable development goals. It indicates that the manifestation of education development goals (particularly SDG no 4, quality education), should be encouraged and sustained by other development fields, including the SDG no 1, poverty elimination since poverty eradication cannot be executed without promoting vulnerable groups' prosperity (United Nations, 2017). It also implicates on sustainable development goal no 2, hunger elimination, the creation of sustained economic growth (SDG no 8), justice for all societies (SDG goal no 16) and global partnership (goal 17) (UNDP, n.d.; United Nations, 2017)

\section{Conclusion}

Vulnerable youth, including the orphans have right to quality education which can open their chances for decent employment. However, to be entitled for this right, they should not be passive citizens. They should be able to develop themselves and be self-educated youth. This study proposes a life skill 
approach for vulnerable youth education promoting their self strength to develop themselves and enabling them to actively obtain their right to education and decent employment. The vulnerable youth also have right for being part of global community. English language and communicative skills and education are some of many accesses to participate in global development. Thus, adding global skill is a basic necessity. This education for right to education is enabled by caring society that provides educational character climate for intergenerational learning. This intergenerational learning may ensure the "left no one behind" in education from generation to generation, as today's generation can be empowering agents for the future generation. Moreover, today's vulnerable youth may have emotional attachment and drive to help as they have direct past experience.

\section{Reference}

Alcantara, A. L. F. (2018). Vulnerable Youth: Background and Policies (No. RL33975; pp. 1-63). Retrieved from Congressional Research Service website: www.crs.gov

Arora, S. K., Shah, D., Chaturvedi, S., \& Gupta, P. (2015). Defining and Measuring Vulnerability in Young People. Indian Journal of Community Medicine, 40(3), 193-197. https://doi.org/doi: 10.4103/0970-0218.158868

Atchoarena, D. (2019). Implement lifelong learning for sustainable development (pp. 1-27). Retrieved from UNESCO Institute for Lifelong Learning website: http://unesco.org/uil

Bankoff, G. (2003). Vulnerability as a measure of change in society. International Journal of Mass Emergencies and Disasters, 21(2), 5-30.

Boomkens, C., Metz, J. W., Schalk, R. M. J. D., \& Van Regenmortel, T. M. R. F. (2019). The role of social environment in acquiring agency in Girls Work. Children and Youth Services Review, 104(104399), 1-9. https://doi.org/10.1016/i.childyouth.2019.104399

Butler, E. P., Taggart, N., \& Chervin, N. (2012). Education, Earning, and Engagement for Out-of-School Youth in 26 Developing Countries: What Has Been Learned from Nine Years of EQUIP3? Journal of International Cooperation in Education, 15(2), 129-158.

Chen, S.-H. (Ava), Nasongkhla, J., \& Donaldson, J. A. (2015). University Social Responsibility (USR): Identifying an Ethical Foundation within Higher Education Institutions. TOJET: The Turkish Online Journal of Educational Technology, 14(4), 165-172.

Claude, R. P. (2005). The right to education and human rights education. International Journal on Human Rights, 2(2), 37-59.

Coomans, F. (2002). Exploring the normative content of the right to education as a human right: Recent approaches. In Core Obligations: Building a Framework Jor Economic, Social and Cultural Rights (pp. 217-246). Antwerp: Intersentia.

Crowther, D., \& Aras, G. (2008). Corporate social responsibility. Ventus Publishing ApS.

Dima, G., Resch, K., Borcos, A., \& Janžekovič, P. (2016). From Corporate Social Responsibility (CSR) to University's Social Responsibility (USR): a reader (Technical Report No. 2015-201; p. DOI: 10.13140/RG.2.2.24751.43686). Retrieved from www.postgraduatecenter.at/unibility

Duffy, V., Hayden, I., \& O'Brien, D. (2017). Peace and Justice: It's up to Youth (pp. 2-50) [Resource Pack]. Ireland: National Youth Council of Ireland and NYCI Development Education Programme.

Emas, R. (2015). The Concept of Sustainable Development: Definition and Defining Principles (pp. 1-3).

English, L. M., \& Carlsen, A. (2019). Lifelong learning and the Sustainable Development Goals (SDGs): Probing the implications and the efects. International Review of Education, 65, 205-211. https://doi.org/10.1007/s11159-019-09773-6 
Esfijani, A., Hussain, F., \& Chang, E. (2013). University social responsibility ontology. Engineering Intelligent Systems, 21(4), 271-281.

EU USR. (2015). Comparative Research on the Social

Responsibility of Universities in Europe

Development of a Community

and

Framework (No. 52709-LLP-2012-1-RO-ERASMUS-ESIN; pp. 1-23). Retrieved from EU USR website: http://www.eu-usr.eu/

Glenn, E. N. (2000). Creating a caring society. Contemporary Sociology, 29(1), 84-94.

Gorur, R. (2015). Vulnerability: Construct, complexity and consequences. In Interrogating Conceptions of "Vulnerable Youth" in Theory, Policy and Practice (pp. 3-15). Retrieved from https://www.sensepublishers.com/

Government of South Australia. (n.d.). Working with Vulnerable Youth Key Concepts and Principles. Retrieved from Office for Youth Department for Communities and Social Inclusion website: www.officeforyouth.sa.gov.au

Hoelman, M. B., Parhusip, B. T. P., Eko, S., Bahagijo, S., \& Santono, H. (2016). Sustainable development goals-SDGs. Panduan Untuk Pemerintah Daerah (Kota dan Kabupaten) dan Pemangku Kepentingan Daerah (pp. 3-74). Jakarta: International NGO Forum on Indonesian Development (INFID).

Huijser, H., Bedford, T., \& Bull, D. (2008). Open Course Ware, Global Access and the Right to Education: Real access or marketing ploy? International Review of Research in Open and Distance Learning, 9(1), 1-13.

Iwuchukwu, J. C., Ogbonna, O. I., \& Agboti, I. O. (2015). Roles of youths groups in rural community development in Ebonyi State, Nigeria. Journal of Agricultural Extension and Rural Development, 7(2), 41-47. https://doi.org/DOI: 10.5897/JAERD2014. 0639

Jokowali, G., Wicaksono, B. T., \& Rosyadi, I. (n.d.). Upaya memosisikan bahasa di dalam masyarakat multilingualisme era mutakhir abad ke-21. Presented at the Presented at the Kongres Bahasa Indonesia.

KPMG. (2017). Lifelong Learning. Creating the Change We Need for the World We Want (pp. 1-26). Retrieved from KPMG International Cooperative website: kpmg.com/uk

Lee, S. E. (n.d.). Education as a Human Right in the 21st Century. Democracy \& Education, 21(1), 1-9.

Lohrenscheit, C. (2002). International Approaches in Human Rights Education. International Review of Education, 48(3-4), 173-185.

ManpowerGroup. (2012). How Policymakers Can Boost Youth Employment (pp. 1-45). Retrieved from ManpowerGroup website: www.manpowergroup.com

Manuel, M., Grandi, F., Manea, S., Kirbyshire, A., \& Lovell, E. (2018). 'Leave no one behind' index 2018. Retrieved from odi.or

Ministry of National Development Planning/, \& National Development Planning Agency. (n.d.). Roadmap of SDGs Indonesia: A Highlight (pp. 1-114). Retrieved from Indonesian Secretariat for Sustainable Development Goals, Ministry of National Development Planning/National Development Planning Agency, Indonesia website: sdgs.bappenas.go.id

Moretti, G. A. S., \& Frandell, T. (2013). Literacy from a Right to Education Perspective (The DirectorGeneral of the United Nations Educational, Scientific and Cultural Organization to Be Submitted to the UN General Assembly at Its 68th Session No. ED/2013/BLS/BAS/PI/1; pp. 1-23). UNESCO.

Nucci, L. P., \& Narvaez, D. (2008). Handbook of Moral and Character Education. New York: Routledge. 
Robeyns, I. (2006). Three models of education: rights, capabilities and human capital. In Press. In Theory and Research in Education (Vol. 4, Issue. 1, pp. 69-84). Retrieved from www.sagepublications.com

Sarker, C., \& Hossain, M. M. (2019). Role of youth organisations in the development of Bangladesh. BRAC Advocacy for Social Change.

Schuster, K. R., \& Pritzker, S. (2015). Strengthening youth participation in civic engagement: Applying the Convention on the Rights of the Child to social work practice. Children and Youth Services Review, 57, 90-97. http://dx.doi.org/10.1016/j.childyouth.2015.07.013

Search for Common Ground. (2018). Youth Impact in Shaping Policy \& Social Cohesion in Myanmar (pp. 2-14). Search for common ground.

Stop Hunger Foundation, \& No Kid Hungry. (n.d.). Youth Engagement Toolkit. Retrieved from www.NoKidHungry.org/YouthToolkit

Strand, K., Marullo, S., Cutforth, N. J., Stoecker, R., \& Donohue, P. (2003). Principles of Best Practice for Community-Based Research. Michigan Journal of Community Service Learning, 9(3), 5-15.

Swick, K. J. (2006). Families and Educators Together: Raising Caring and Peaceable Children. Early Childhood Education Journal, 33(4), 279-287. https://doi.org/DOI: 10.1007/s10643-005-0033-3

The Inter-Parliamentary Union, \& The United Nations (Office of the High Commissioner for Human Rights). (2016). Human Rights. Handbook for Parliamentarians No 26. Retrieved from www.ipu.org; www.ohchr.org

The World Bank. (2006). Development and the Next Generation (World Development Report No. 35999; pp. 1-305). Washington, D.C.: The International Bank for Reconstruction and Development / The World Bank.

Tomasevski, K. (2003). Education Denied. London and New York: Zed Books.

Torjman, S. (1998). Strategies for a Caring Society. 1-22. Retrieved from www.caledoninst.org

Trucco, D., \& Ullmann, H. (2016). Youth: realities and challenges for achieving development with equality. Santiago: Economic Commission for Latin America and the Caribbean (ECLAC).

UNDP. (2014). UNDP Youth Strategy 2014-2017. Empowered Youth, Sustainable Future (pp. 1-50). New York: United Nations' Development Programme.

UNDP. (2018). What does it mean to leave no one behind? A UNDP discussion paper and framework for implementation. the United Nations Development Programme (UNDP) Bureau for Policy and Programme Support.

UNDP. (2019). SDGs in Indonesia: 2018 and beyond. Retrieved from Indonesia website: https://www.id.undp.org/content/indonesia/en/home/presscenter/articles/2018/sdgs-inindonesia--2018-and-beyond.html

UNDP. (n.d.). Sustainable Development Goals. Retrieved from https://www.undp.org/content/dam/undp/library/corporate/brochure/SDGs_Booklet_Web_En.p df

UNESCO. (2000a). The Dakar framework for action: Education for all: Meeting our collective commitments (including six regional framework for meeting) (Programme and Meeting Document No. ED.2000/WS/27; pp. 1-77). Retrieved from UNESCO website: www.unesco.org

UNESCO. (2000b). The right to education: towards education for all throughout life (pp. 9-173) [World education report 2000]. UNESCO Publishing. 
UNESCO. (2005). Report of the Inter-Agency Working Group on Life Skills in EFA (Programme and Meeting Document No. ED/PEQ/IQL/2005/RP/H/1; pp. 1-14). Retrieved from https://unesdoc.unesco.org/ark:/48223/pf0000141012?posInSet=1\&queryId=a7e4ee4f-9e4049fc-aefd-227397411a28

UNESCO. (2015). Contributing to a more sustainable future: quality education, life skills and education for sustainable development (Programme and Meeting Document No. ED/PEQ/IQL/2005/PI/H/2; pp. 1-8). Retrieved from UNESCO website: http://www.unesco.org/education

UNESCO. (n.d.). Education transforms lives (Programme and Meeting Document No. ED.2017/WS/3). Retrieved from UNESCO Education Sector website: www.unesco.org/education www.facebook.com/unesco @UNESCO www.youtube.com/unesco www.linkedin.com/company/unesco (join UNESCO's Group on Education) plus.google.com/+UNESCO/posts

UNICEF. (2007). A Human Rights-Based Approach to Education for all. A framework for the realization of children's right to education and rights within education. Retrieved from ISBN. ISBN: 978-92-8064188-2

Unicef. (2012). Global evaluation of lifeskills education programmes (pp. 1-148) [Evaluation Report]. Retrieved from Evaluation Office website: evalhelp@unicef.org

Unicef. (2017). Reimagining Life Skills and Citizenship Education in the Middle East and North Africa A Four-Dimensional and Systems Approach to 21st Century Skills. Conceptual and Programmatic Framework (pp. 1-167). Jordan: UNICEF MENA Regional Office.

Unicef. (n.d.-a). Introduction. Retrieved from unicef-for every child website: https://www.unicef.org/lifeskills/

Unicef. (n.d.-b). Life Skills for Young Ugandans-Secondary Teachers' Training Manual. Retrieved from http://www.nzdl.org/

United Nations. (2017). The Sustainable Development Goals Report (pp. 2-60). Retrieved from United Nations website: ISBN 978-92-1-101368-9

United Nations. (2018). Youth and the 2030 agenda for sustainable development (pp. 1-210). New York: United Nations.

United Nations. (n.d.). Transforming our World: The 2030 Agenda for Sustainable Development (No. A/RES/70/1; pp. 3-36). Retrieved from United Nations website: sustainabledevelopment.un.org

United Nations-Indonesia. (n.d.). Sustainable Development Goals (SDGs). Retrieved from https://www.un.or.id/what-we-do/sustainable-development-goals-sdgs

Wade, R. C. (1995). Developing Active Citizens: Community Service Learning in Social Studies Teacher Education. Service Learning , General. Paper 36. Retrieved from http://digitalcommons.unomaha.edu/slceslgen/36

Ward, K., \& Wolf-Wendel, L. (2000). Community-centered service learning. Moving from doing for to doing with. The American Behavioral Scientist, 43(5), 767-780.

Webb, S., Holford, J., Hodge, S., Milana, M., \& Waller, R. (2019). Conceptualising lifelong learning for sustainable development and education 2030. International Journal of Lifelong Education, 38(3), 237-240. https://doi.org/DOI: 10.1080/02601370.2019.1635353

World Health Organization. (1999). Partners in Life Skills Education. Conclusions from a United Nations Inter-Agency Meeting (No. WHO/MNH/MHP/99.2; pp. 1-13). Geneva: Department of Mental Health World Health Organization.. 